\title{
Fiscal Deficit of the Public Sector in India: Issues on Data Reliability, Accounting Flaws and Missing Variables
}

\author{
K. A. Aneesh \\ Research Scholar, Centre for Economic Studies and Planning (CESP), School of Social Sciences (SSS), \\ Jawaharlal Nehru University (JNU), New Delhi, India \\ E-Mail: aneeshka99@gmail.com
}

\begin{abstract}
Fiscal deficit, one of the widely acclaimed and internationally accepted measures of fiscal imbalance, is faced with a lot of conceptual and accounting issues in India. The definition of deficit has been changing and therefore there is no consistency in the official series of deficits published by the government of India. Since 1991, budgets were being framed in the context of the New Economic Policies (NEP) consisting of the Stabilization Policies and the Structural Adjustment Policies (SAP). While, the fiscal austerity in the form of expenditure reduction and revenue enhancement as a corollary to NEP has hardly worked out in India. However, the Central government has undertaken several measures to show a reduced fiscal deficit in India. One of the ways practiced was to implement some changes in the accounting practices over the years. This was by including some additional elements in the definition of deficit and excluding some other items. The second practice was to transfer the deficit of the Centre to other layers of the government. In a broad fiscal policy regime framework following Prof. Arun Kumar's modified National Income Identity (1988), a total government or public sector comprising of the Centre, State/UTs and local-selfgovernments as well as the Public Sector Enterprises (PSEs) at the Centre and State levels. The problem of deficit shifting can be automatically avoided by taking the whole public sector into the analysis, which makes the empirical results on interrelationship between fiscal deficit and various macroeconomic variables more realistic and convincing. Still, there is a paucity of white economy data, because of the existence of substantial black economy in India. Its noninclusion in analysis results in a partial understanding of the economy and often incorrect policy pronouncements. The need to incorporate the black economy is not simply an empirical matter, but a theoretical necessity. This paper in general tries to bring the aforementioned issues on data reliability, accounting flaws and missing variables into the discussion and attempt to correct the fudges in the official deficit series published by the government and also tries construct a compiled series of deficit for the public sector in India. The empirical section of the paper explains the significance of black economy as a variable to be included in the analysis to get better understanding of the economy.

Keywords: Fiscal deficit, Public sector in India, Fiscal policy regime, National income identity, Black economy
\end{abstract}

\section{INTRODUCTION}

The term fiscal deficit is relatively new in the Indian public finance lexicon. The fiscal deficit found its place in the 1991-92 budget document of the government of India. In India fiscal deficit is defined as the excess of expenditure over revenue and non-borrowed capital receipts. "Since
1991, budgets were being framed in the context of the New Economic Policies (NEP) consisting of the Stabilization Policies and the Structural Adjustment Policies (SAP)" (Kumar, 1994: 953). The stabilization policies introduced in India as a corollary to the economic reform measures in 1991 were mainly to reduce the fiscal deficit of the country especially the Central government's fiscal deficit. Since then the Central government has undertaken several measures to show a reduced fiscal deficit in India. One of the ways practiced was to implement some changes in the accounting practices over the years. This was by including some additional elements in the definitions of deficit and excluding some other items. The second practice was to transfer the deficit of the Centre to other layers of the government, viz. state governments and union territories and the public sector undertakings in the Centre as well as in the state level.

The definition of the fiscal deficit of the Central government has undergone changes especially after NEP. The consistency of the official series of the fiscal deficit of the Centre should be suspect after 1991 as the government's effort since then was to show lower deficit figures. Most of the years, the government's budget estimates of the deficit measures are lower than the actual estimates. The accounting changes in the form of excluding and including some items and transferring some items to other layers of government are practiced by the government to show lower deficit figures of the Centre.

\section{CHANGES IN ACCOUNTING PRACTICES}

The discrepancies between the budget, the revised and the actual figures are notable. Usually errors in the budget estimates are corrected in the actual figures with the sign of the error changing. Since reforms the errors are showing large and mostly in the same direction. Kumar (1994) noted that since the Union Budget 1992-93 the wide variations are clear and visible. A comparison of the budget estimates with the revised and the actual estimates of the deficits reveal the fudges. Bhattacharya (1991) observed that all this happened despite periodical monitoring of deficits by parliament. Kumar (1994) argued that the intension was to demonstrate a healthier growth of the economy and to indicate fiscal prudence. 
A comparison of the actual figures of fiscal deficit with the budget and the revised estimates of the same reveals that the budget estimate of the fiscal deficit was lower than the actual figures since 1991-92. While the trend goes changed after 2003-04 with the implementation of the Fiscal Responsibility and Budget Management Act (FRBMA). The FRBM rule specifies reduction of fiscal deficit to 3 per cent of the GDP by 2008-09 with annual reduction target of 0.3 per cent of GDP per year by the Central government. Similarly, revenue deficit has to be reduced by 0.5 per cent of the GDP per year with complete elimination to be achieved by 2008-09 (MoF, 2004). The fiscal deficit target laid out by the government's FRBM Act was achieved in 2007-08, a year ahead of scheduled. Again there has shown a reversal in trend in the years 2008-09 and 2009-10 because of the effects of global economic slowdown. Till the implementation of the FRBM Act, in three years the budget estimates come even less than 80 per cent of the actual figures of fiscal deficit. In 1998-99 the ratio was just 80.31 per cent. In 2008-09 this ratio came 39.5 per cent due to economic recession. The budget estimates of the fiscal deficit grown slowly than its revised and actual figures till the implementation of FRBM Act. The revised estimates were also higher than the budget estimates except in the years 2003-04, 2005-06 and 2007-08. Thus every year government has tried to show that this time the government becomes successful in reducing the situation of high deficit.

\section{DEFICIT TRANSFERRING}

By practicing several accounting exercises some crucial items are either not counted or transferred to other layers of the government. Therefore, reduction of the central government deficit by mere transfer leads to consequent increase in the deficits of the other layers of government and the public sector undertakings. Some of the major practices used are: (1) sharing of small savings with the state governments/UTs; (2) granting of extra budgetary resources (EBR) to public sector enterprises (PSEs) and (3) the handling of disinvestment proceeds in government accounts.

\section{A. Small Savings and Fiscal Deficit of the Central Government}

Central government plays an important role of financing intermediaries in collection of the small savings and these are shared with the state governments. The outstanding amount under small savings collection constitutes the liabilities of the central government and the net collections were being shared with the state governments in the form of long term loans for financing the State plans. The sharing ratio of net collection of small savings between the Centre and states/UTs has been changing from time to time. Earlier, two-third of the net collection was passed on as long term loans to states. The share of states gradually increased over the years and since 2002 the total net collection goes to the state governments. This additional burden on the state governments reflected in the increased figures of deficit of the states/UTs. While the central government's fiscal position shows slight improvements. In the financial year 2013-14, the net small savings transferred to the state governments is Rs.18989 crores, which accounts for around 7.8 per cent of the fiscal deficit of the states (MoF, 2011). While this accounting transfer benefits the central government by reducing around 3.8 per cent of its fiscal deficit.

There is a major accounting change in the central government's method of calculating fiscal deficit since April 1, 1999. "With the change in the system of accounting with effect from 1999-2000, state's share in small savings, which was included earlier under loans from the Centre, is shown separately as special securities issued to National Small Savings Fund (NSSF) under internal debt” (Handbook of Statistics 2013-14, p. 189). NSSF was created in the Public Accounts of India and all collections/ disbursements under small savings certificates, deposits and public provident funds are made in to/out of this fund. Prior to the formation of NSSF, small saving shares of states were accounted as non-plan expenditure of the central government. Since April 1, 1999, withdrawals of fund from NSSF are not counted as expenditure to determine the size of the Center's gross fiscal deficit. The following table (Table I) presents the size of the fiscal deficit since 19992000 to the present and compared with the new accounting criteria. Under the new accounting system, the gross or net fiscal deficit of the Centre is reduced by the amount of share of states in small savings collection. The reduction of fiscal deficit due to this change is substantial as presented in the above table.

TABLE I NSSF AND REDUCTION IN FISCAL DEFICIT OF THE CENTRE

\begin{tabular}{|c|c|c|c|}
\hline Year & $\begin{array}{c}\text { Fiscal Deficit } \\
\text { without NSSF }\end{array}$ & $\begin{array}{c}\text { FD with } \\
\text { NSSF }\end{array}$ & $\begin{array}{c}\text { \% Reduction } \\
\text { in FD }\end{array}$ \\
\hline $1999-2000$ & 104716 & 129967 & 19.42 \\
\hline $2000-01$ & 118816 & 149917 & 20.74 \\
\hline $2001-02$ & 140955 & 174829 & 19.37 \\
\hline $2002-03$ & 145072 & 194038 & 25.23 \\
\hline $2003-04$ & 123273 & 186086 & 33.75 \\
\hline $2004-05$ & 125794 & 209493 & 39.95 \\
\hline $2005-06$ & 146435 & 225011 & 34.92 \\
\hline $2006-07$ & 142573 & 201329 & 29.18 \\
\hline $2007-08$ & 126912 & 138006 & 8.03 \\
\hline $2008-09$ & 336992 & 345512 & 2.46 \\
\hline $2009-10$ & 418482 & 425019 & 7.41 \\
\hline $2010-11$ & 373591 & 427180 & 12.54 \\
\hline $2011-12$ & 515990 & 526514 & 1.99 \\
\hline $2012-13$ & 490190 & 512015 & 4.26 \\
\hline $2013-14$ & 502858 & 527568 & 4.68 \\
\hline $2014-15$ & 510725 & 557232 & 8.32 \\
\hline $2015-16$ & 532791 & 565922 & 5.85 \\
\hline $2016-17$ & 534274 & 563484 & 5.18 \\
\hline Sour & 5695 & \\
\hline
\end{tabular}

Source: Handbook of Statistics and Economic Survey, various issues 


\section{B. Extra Budgetary Resources and Fiscal Deficit of the Central Government}

Jalan (1992) argues that "to a large extent, the fiscal crisis of the central government is a reflection of the financial crisis of the public sector. An important reason for the state of 'fiscal incapacity' is the failure of public sector enterprises to generate adequate revenue or return on past investments” (p. 21). The financing of the loss making PSEs and a heavy budgetary support to them have increased the fiscal deficit of the Centre as the central public sector enterprises (CPSEs) were part of the accounts of the central government earlier. The central government separated the accounts of the CPSEs after the mid-Eighties. The budgetary support given to CPSEs was cut short and they were compelled to generate internal resources for financing their own expansion and developmental activities.

A component of the gross internal resources generated by each enterprise is utilized for repayment of loans, additional working capital requirements, meeting non-plan capital requirements, etc. Therefore, the total internal resources generated are not always available for financing the Plan schemes. What are left after utilization internally are the net internal resources of the PSEs which are used for financing their Plan schemes. The share of net internal resources in the Plan outlay of CPSEs has grown gradually and it is around 74 per cent of the plan outlay in 2013-14 compared to 34 per cent in 1985-86. At the same time the budgetary support shows a steep decline to 3.83 per cent of the plan outlay in 2013-14 from a peak of 50.57 per cent in 1985-86. This reduced budgetary support has been compensated by the Internal Extra Budgetary Resources (IEBR), which show a sharp hike after the Sixth Plan period.

The IEBR of the PSEs comprises of the net internal resources and the extra budgetary resources (EBR) of PSEs. EBR as a per cent of plan outlay of CPSEs has shot up to 45 per cent in 2012-13 from a low 16 per cent in 1985-86, an increase of nearly threefold. Thus, transfers from the Central government to the PSEs have decreased and now more burden is put on them. This has implications for the deficits of CPSEs because they have to finance their plan outlay through borrowings. Correspondingly, the extent of the fiscal deficit of the Centre shows a decline. In fact, EBRs are the borrowings of the PSEs, which should be adjusted with the fiscal deficit of the Central government to construct a consistent series of its deficit.

\section{Disinvestment and Fiscal Deficit of the Central Government}

Disinvestment proceeds, which did not exist before 1991-92 are included in the capital receipts in India but are considered as revenue receipts in the definition of fiscal deficit of IMF and WB. There is an extensive discussion in the literature on disinvestment proceeds, whether to include it as revenue receipts or capital receipts. Mansoor (1988) discussing the above issue in detail argued that since the portfolio of government due to disinvestment does not change i.e., government only exchanges public asset with cash; disinvestments have no impact on the financial position of the government.

One view is that disinvestment proceeds are used to repay the borrowing and the disinvested PSEs are loss making, then it will gain in the future by the amount of interest payment and the loss of the PSEs. In the case of repayment of loans, it will be like investment, so disinvestment in this case should be taken as capital item. If disinvestment proceeds are used to finance current expenditure, then it should be included in the revenue receipts.

In India, the central government is using disinvestment proceeds neither for restructuring of the loss making public sector nor for liquidation of public debt as was the initial declared objective of the disinvestment. The proceeds are being used to finance the deficits in the current account. So, in this argument, disinvestment should be considered in the current (revenue) receipts. Fiscal deficit of the government will go down by the amount of disinvestments.

However, Mansoor (1988) shows that it is one-shot game and it reduce the present borrowing requirements at the cost of higher future deficit.

In Kumar (1994) disinvestment is treated as negative investment by the public sector and netted out of the total capital expenditure by the government. The deficit stands reduced. The private sector which purchases the assets then reduces investment elsewhere. Hence, total investment in the economy stands reduced as a result of the disinvestment.

Chelliah (1996) argued that if the short term impact of the budget on aggregate demand through the net borrowing is to be judged, the sale proceeds of assets could be netted against capital formation expenditure. In this case, the sale proceeds will not be shown as a source of financing deficit. However, if one wishes to measure the extent of the fiscal correction or adjustment in a situation where the size of the fiscal deficit has been too high, it would seem to be appropriate to consider the reduction in the deficit without taking into account the yield from the sale of assets. For this purpose, the sale proceeds should be taken to be an item financing capital expenditure. Chelliah's suggestion is clearly situational which cannot be accepted if one is wishing for a consistent deficit measure.

In the year the government is successfully able to get relatively large disinvestment proceeds, the deficit figure is artificially reduced. Thus for consistency and comparability it should be included in the fiscal deficit of the Centre.

Ruling out the small savings share of states and disinvestment proceeds from the calculation of fiscal deficit of the Centre, government could be able to reduce its fiscal deficit a great extent. In 1998-99 central government could make a 48 per cent reduction in its fiscal deficit only by practicing this accounting change. 


\section{Recapitalization of Banks}

As part of the efforts to augment the capital base of the public sector banks in conformity with the Basle norm of 8 per cent capital to risk weighted asset ratio (CRAR), the government has contributed a total Rs.9152.33 crore in three consecutive years of 1994-95, 1995-96 and 1996-97 (Economic Survey 1997-98: 34-41). Contribution of the government for the recapitalization of public sector banks should be included in the fiscal deficit of the Centre in corresponding three years. Major accounting changes and transfers we identified are adjusted with the official fiscal deficit of the central government. The new consistent series of fiscal deficit after adjusting the fudges in official fiscal deficit is shown in the following table (Table II).

TABLe I Consistent Series Of Fd Of The Central Government Of India

\begin{tabular}{|c|c|c|c|c|c|c|}
\hline Year & $\begin{array}{c}\text { Official Fiscal } \\
\text { Deficit }\end{array}$ & $\begin{array}{c}\text { Small Savings Transfers } \\
\text { to States/UTs }\end{array}$ & $\begin{array}{l}\text { Disinvestment } \\
\text { Proceeds }\end{array}$ & $\begin{array}{l}\text { EBR of } \\
\text { CPSEs }\end{array}$ & $\begin{array}{c}\text { New Series of } \\
\text { FD }\end{array}$ & $\%$ of GDP \\
\hline $1980-81$ & 8299 & 2242 & 0 & NA & 10541.00 & 7.04 \\
\hline 1981-82 & 8666 & 2798 & 0 & NA & 11464.00 & 6.52 \\
\hline 1982-83 & 10629 & 3446 & 0 & NA & 14075.00 & 7.16 \\
\hline 1983-84 & 13030 & 4816 & 0 & NA & 17846.00 & 7.79 \\
\hline 1984-85 & 17416 & 7302 & 0 & NA & 24718.00 & 9.63 \\
\hline 1985-86 & 21858 & 8584 & 0 & 1559.19 & 32001.20 & 11.05 \\
\hline 1986-87 & 26342 & 6552 & 0 & 2686.92 & 35580.90 & 10.98 \\
\hline $1987-88$ & 27044 & 10899 & 0 & 3270.50 & 41213.50 & 11.19 \\
\hline 1988-89 & 30923 & 16425 & 0 & 4607.14 & 51955.10 & 11.89 \\
\hline 1989-90 & 35632 & 23874 & 0 & 5929.87 & 65435.90 & 13.04 \\
\hline 1990-91 & 44632 & 24927 & 0 & 7696.74 & 77255.70 & 13.18 \\
\hline 1991-92 & 36325 & 16962 & 3037.74 & 7987.82 & 64312.60 & 9.54 \\
\hline 1992-93 & 40173 & 13119 & 1912.51 & 11001.43 & 66205.90 & 8.55 \\
\hline 1993-94 & 60257 & 21471 & 0 & 14743.93 & 96471.90 & 10.82 \\
\hline 1994-95* & 57703 & 43341 & 4843.10 & 13445.53 & 124620.00 & 11.92 \\
\hline 1995-96* & 60243 & 30312 & 168.48 & 12674.02 & 105754.00 & 8.62 \\
\hline 1996-97* & 66733 & 36522 & 379.67 & 16901.23 & 122045.00 & 8.60 \\
\hline $1997-98$ & 88937 & 61389 & 910.00 & 14912.25 & 166148.00 & 10.57 \\
\hline 1998-99 & 113348 & 99105 & 5371.11 & 12280.46 & 230105.00 & 12.76 \\
\hline $1999-2000$ & 104716 & 26937 & 1860.14 & 17700.37 & 151214.00 & 7.47 \\
\hline 2000-01 & 118816 & 33264 & 1871.26 & 18007.71 & 171959.00 & 7.90 \\
\hline 2001-02 & 140955 & 35020 & 5657.69 & 24713.19 & 206346.00 & 8.76 \\
\hline 2002-03 & 145072 & 52261 & 3347.98 & 21017.05 & 221698.00 & 8.74 \\
\hline 2003-04 & 123273 & 67642 & 15547.40 & 26855.66 & 233318.00 & 8.21 \\
\hline 2004-05 & 125794 & 87690 & 2764.87 & 26006.52 & 242255.00 & 7.47 \\
\hline 2005-06 & 146435 & 89836 & 1569.68 & 35723.30 & 273564.00 & 7.41 \\
\hline 2006-07 & 142573 & 63746 & 0 & 32676.47 & 238995.00 & 5.56 \\
\hline 2007-08 & 126912 & 12194 & 4181.39 & 38692.82 & 181980.00 & 3.65 \\
\hline 2008-09 & 336992 & 8410 & 0 & 57807.92 & 403210.00 & 7.16 \\
\hline 2009-10 & 418482 & 34862 & 23552.90 & 65633.85 & 542531.00 & 8.38 \\
\hline 2010-11 & 373591 & 53589 & 22144.20 & 56174.62 & 505499.00 & 6.49 \\
\hline 2011-12 & 515990 & 10524 & 13894.10 & 78921.04 & 619329.00 & 6.87 \\
\hline 2012-13 & 490597 & 12979 & 23956.10 & 81186.04 & 608718.00 & 6.02 \\
\hline 2013-14 & 502858 & 18989 & 15819.50 & 47514.74 & 585181.00 & 5.15 \\
\hline
\end{tabular}

*Bank recapitalization is adjusted with the total figure.

Note: Last two columns are calculated on the basis of official data from the sources mentioned below. Source: RBI Handbook of Statistics on the Indian Economy 2013-14; Indian Public Finance Statistics 2013-14; Public Enterprises Survey, various issues and Economic Survey, various issues. 
The percentage increase in consistent measure of fiscal deficit with that of the official one varies in each year and period depending on the quantum of transfer/shift of deficits to other layers of government and PSEs. The average increase during the whole period is around 56 per cent. The average increase during the 90s itself account for around 78 per cent, but in 2000s it is a slightly low of around 57 per cent. Transfer of deficit from Centre to other layers of government was significant during the 90s. In 1994-95 the new consistent fiscal deficit constructed is around 116 per cent higher than the official deficit of the Centre. It accounts for the adjustment made in net collection of small savings shared with states and the disinvestment proceeds. Both the figures were quite high in this year to make a considerable hike in consistent series of deficit after adjusting the same in the series (see Figure 1).

In 1998-99 also the change is more than 100 per cent because of the adjustment of small savings, which was the highest amount shifted to the state governments since 1980 . The disinvestment proceeds in that year were also high, around 6 times higher than the proceeds in the previous year. A significant increase during 2000s happened in the year 2004-05. It was due to the adjustment of high disinvestment proceeds with the fiscal deficit.

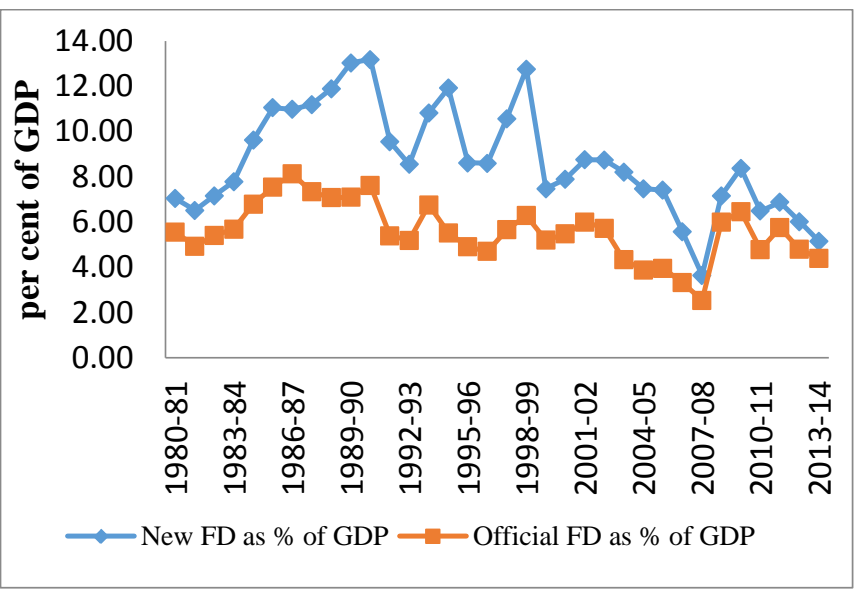

Source: Plotted on the basis of Table II Fig. 1 A Comparison of Official and Consistent Series of Fiscal Deficits of the Central Government

Even though the trend followed in both the series are almost same, the differences are wide. The gaps are reasonably large in 1990s. But in the later periods of our analysis the gaps are gradually declining.

\section{FISCAL DEFICIT OF THE PUBLIC SECTOR IN INDIA}

Kalecki (1971) presents the national income identity in a different form by avoiding some of the shortcomings of the Keynesian identity. He assumed two classes in society:

capitalists and workers. Capitalists are those earning property incomes and others are treated as wage earners. Kalecki has shown that the post-tax profit can be written as,
$\left(\mathrm{P}-\mathrm{T}_{\mathrm{p}}\right)=$ Budget deficit $+($ Export-Import $)+$ Investment + Capitalist's Consumptions - Workers Savings

Where, $\mathrm{P}=$ Gross Profit

$\mathrm{T}_{\mathrm{p}}=$ Tax on Profit

Kalecki explicitly incorporated causation which runs from expenditures to income (right to left) and the effect of distribution is explicit.

Kumar (1988) with some modifications used the Kaleckian identity for analyzing the fiscal policy regime in India. He modified the Kaleckian framework in the case of an actual economy having various layers of government. Further Kumar (1988) pointed that since there is a public sector, gross profit $(\mathrm{P})$ should also include the surplus generated by the public sector. As a part of the surplus of public enterprises accrues as taxes, another as dividends and interest payments and the reminder as support for further public investments or internal accruals, Kumar noted that $\mathrm{T}_{\mathrm{p}}$ in the Kaleckian analysis represents the tax on private profits alone. He is assuming a balanced foreign trade and no savings among workers. Further he defines budget deficit as the difference between government expenditures plus transfers and the government revenue.

Government expenditures (G) may be written as, $\mathrm{G}=$ Consumption of Government $\left(\mathrm{C}_{\mathrm{g}}\right)+$ Support to Public Sector $\left(\mathrm{S}_{\mathrm{p}}\right)+$ Public Investment $\left(\mathrm{I}_{\mathrm{g}}\right)+$ Subsidy $(\mathrm{S})$ (2)

And, government revenue $(\mathrm{R})$ can be written as, $\mathrm{R}$ = Tax Revenue $(\mathrm{T})+$ Non-Tax Revenue $(\mathrm{NT})$

$\mathrm{T}=$ Direct Taxes (DT) + Indirect Taxes (IT)

$\mathrm{NT}=$ Public Sector Surplus $\left(\mathrm{R}_{\mathrm{p}}\right)+$ Net Borrowing B)

Kumar (1988) pointed that interest payments by the government (I) is a payment for the debt which goes to the section having surpluses. As mentioned in our assumptions, capitalists are the only class earning property incomes and workers do not save, the entire interest payments go to the profit earners. This should be added to the left hand side of the equation (1). Other transfers to the profit earners like, pensions, etc., should also be added to the left hand side of the equation (1). These transfers should have corresponding effect on the level of budgetary deficit, which is shown on the right hand side of the equation (1).

The narrow definition of budget deficit, which is widely used in India, does not include borrowings (B) as a part of the deficit. So,

Budget Deficit $=\mathrm{G}+\mathrm{I}-\mathrm{R}$

As Kumar (1988) states if borrowings by the government is out of the profits of the private sector, Kalecki's National Income Identity (equation 1) can be rewritten as follows:

$\left(P_{P}-T_{P}\right)+I+G_{P}-B=B D+C A B+I_{P}+C_{C}$ 
Where, I = Interest Payments by the Government

$\mathrm{B}=$ Borrowings by the Government from the Private

Sector

$\mathrm{P}_{\mathrm{p}} \quad=$ Profit of the Private Sector

$\mathrm{G}_{\mathrm{p}} \quad=$ Surplus of the Public Sector

$\mathrm{I}_{\mathrm{p}} \quad=$ Investment by the Private Sector

$\mathrm{C}_{\mathrm{c}} \quad=$ Capitalist Consumption

$\mathrm{BD}=$ Budget Deficit

$\mathrm{CAB}=$ Current Account Balance

From equation (5) we get,

$P_{P}-T_{P}+I=(B D+B)+I_{P}+C_{C}+C A B$

$P_{P}-T_{P}+I=(G+I-R+B)+I_{P}+C_{C}+C A B$

$(\mathrm{G}+\mathrm{I}-\mathrm{R}+\mathrm{B})$ or $(\mathrm{BD}+\mathrm{B})$ may be called as the wider definition of budget deficit including market borrowing and other forms of borrowing. It is also termed as the fiscal deficit (FD) of the country.

Primary deficit is defined as the fiscal deficit netted with the interest transfers (ie. PD = FD - I). If we consider primary deficit in the right hand side of the equation (7), some transfers come common to both sides of the equation and will be cancelled out without making any change in the level of gross profits.

$\left(P_{P}-T_{P}\right)=[(B D+B)-I]+I_{P}+C_{C}+C A B$

The rest of the transfers which affect the level of gross profits should be excluded from the deficit. Similarly, as mentioned earlier, all layers of the government should be taken into consideration. Then the equation (8) can be written as follows:

$\left(P_{P}-T_{P}\right)=M P D+I_{P}+C_{C}+C A B$

Where, MPD is the Modified Primary Deficit, which considers all layers of the governments and netted rest of the transfers entering both sides of the equation (8). Kumar (1988) recommends the above identity to analyze the effectiveness of the fiscal policy.

\section{BLACK ECONOMY IN INDIA}

Kumar (1999a and 1999b) strongly argues that besides all the above deficiencies there is paucity of white economy data because of the existence of substantial black economy in India. Its non-inclusion in analyses resulted in a partial understanding of the Indian economy and often incorrect policy pronouncements. The need to incorporate the black economy is not simply an empirical matter, but a theoretical necessity.

Kumar (1999b) analyses the national income identity with a black economy component identifies a black economy part along with a white economy part in all the variables in the equation (9) except for $T_{p}$, B and I.

1. Undeclared Profits: White profits are the ones declared for tax purposes and $T_{p}$ are the taxes paid out of them. No taxes are paid out of black gross profits since they are undeclared. So $\mathrm{P}_{\mathrm{p}}$ needs to be separated into two parts: white private gross profits $\mathrm{P}_{\mathrm{wp}}$ and black private gross profit $\mathrm{P}_{\mathrm{bp}}$.

2. Capitalist Consumption and Black Incomes: Consumption intensity out of black incomes is larger than out of the white incomes and also more import intensive. The goods consumed using black incomes do not necessarily originate in the black economy. Similarly, white incomes may be used to purchase goods or services produced in the black economy. Hence no useful purpose is served in writing the black and white components separately.

3. Black Investments: Private investment $\mathrm{I}_{\mathrm{p}}$ needs to be split into a black and a white component, $\mathrm{I}_{\mathrm{pb}}$ and $\mathrm{I}_{\mathrm{bw}}$. The black components are not necessarily come out of black incomes and the white not necessarily out of white incomes only.

4. Budget Deficit and Public Sector - The impact of black economy on the budget deficits is both because expenditures are inflated and revenues are less. Its effect on the budget is that instead of showing a primary fiscal surplus there is a deficit.

5. Black Economy and the External Sector- The true (X-M) term needs to be separated into its black and white components with the latter reflecting the official data and the former the remaining part.

After incorporating the black economy components in all such variables, the national income identity, as given in equation (6) above, can be modified as follows:

$\left(P_{p w}-T_{p}\right)+P_{p b}+I=[$ Budget Deficit $+B]+I_{p w}+$ $I_{p b}+C_{c}+\quad(X-M)_{w}+(X-M)_{b}$

There are several attempts by various economists to measure the size of black economy in India. In 1955-56, it was estimated by Prof. Kaldor to b 4-5 per cent of GDP (Kumar 1999a, 2017). Acharya and associates (1985) estimated the size of black economy to be 20 per cent of the white economy for 1980-81. Gupta (1992) estimated it to be 51 per cent for 1987-88. Kumar and Sen (1993) estimated a figure of 30 per cent for 1990-91. Kumar (1999a) estimated a size of 40 per cent for 1995. It was estimated to be 62 per cent of GDP for 2012-13 (Kumar 2015, 2017). If it is assumed to be the same in 2016-17, the black economy amounts to Rs.93 Lakh crore. Hence, it cannot be ignored. As we already mentioned, if we incorporate the black economy into calculation we get a budgetary surplus rather than a deficit with every definition. However, the data on black economy is not available for a continuous period and consistent method; we have strong limitation in incorporating black economy in the calculation of deficits.

\section{EMPIRICAL RESULTS}

Analysis on the basis of white economy data with official series of deficits showed poor and incomplete results. So the same analysis was repeated in the black economy framework and with the consistent series of deficits 
constructed. The results improved significantly and the beta coefficients of the variables were as expected.

The role of the black economy in all the modified models was found to be highly significant in explaining the macroeconomic variables in India. Considering the level of significance, the modified primary deficit is found to be the best proxy and the primary deficit a next best measure of deficit significant in the framework of national income identity in India. The result is consistent with the theoretical arguments in Kumar (1988) and Kumar (1999).

If we consider Adj. $\mathrm{R}^{2}$ in each model as an indicator of explanatory power, the results point to the same conclusion (see Table 3). It shows an improvement when we added more layers of government and black economy in to the analysis.

The model with consistent MPD in a black economy framework shows better Adj. $\mathrm{R}^{2}$ than the combined models of FD and PD without including black economy variable.

TABLE III CHANGE IN ADJ. $\mathrm{R}^{2}$ IN MODELS OF NATIONAL INCOME

\begin{tabular}{|l|c|c|c|}
\hline $\begin{array}{c}\text { Layers of Public } \\
\text { Sector Considered }\end{array}$ & OFD & NFD & $\begin{array}{c}\text { NFD with } \\
\text { Black }\end{array}$ \\
\hline Centre & .9339 & .9221 & .9782 \\
\hline Centre + States/UTs & .9347 & .9097 & .9775 \\
\hline $\begin{array}{l}\text { Centre + } \\
\text { States/UTs+ CPSEs }\end{array}$ & .9288 & .9289 & .9756 \\
\hline \multicolumn{3}{|c|}{ Source: Estimates from Stata12 }
\end{tabular}

\section{CONCLUSION}

Inclusion of the black economy variable with various layers of government shows an improvement in the Adj. $\mathrm{R}^{2}$ of the models. The Adj. $\mathrm{R}^{2}$ of the model with consistent FD of the public sector and black economy variable is .9756 which is much higher than the Adj. $\mathrm{R}^{2}$ of the model with consistent FD only. So far all the empirical works which has been done by the Indian economists have large errors (see Rakshit, 2005 and Rangarajan, 2009), because of not counting the black economy in the analysis. In the present study, the role of black economy has turned out to be highly significant in explaining the change in the dependent variables. The exclusion of black economy in the analysis leads to incomplete results and therefore false policy propositions.A step by step correction of problems in the model and inclusion of missing variables improves the result in our analysis. The impact of black economy is highly significant since its exclusion in the analysis gives poorer results. Similarly, the whole public sector should be considered in the analysis incorporating all layers of government and public sector enterprises to get better conclusions, but lack of availability of data did not allow this to be tested fully.

\section{REFERENCES}

[1] Acharya, S. and Associates (1985). Aspects of the Black Economy in India, NIPFP, New Delhi.

[2] Bhattacharya, B. B. (1991), (August 24), Macro Imbalances, Stabilization Programme and Union Budget, Economic and Political Weekly, 2005-2009.

[3] Chelliah, R. J. (1996). Towards Sustainable Growth: Essays in Fiscal and Financial Sector Reforms in India, OUP, New Delhi.

[4] Government of India, Ministry of Finance, Budget at a Glance, Various Issues.

[5] Government of India, Ministry of Finance, Economic Survey, Various Issues.

[6] Government of India, Ministry of Finance, Report of the Committee on Comprehensive Review of National Small Savings Fund, June 2011.

[7] Government of India, Ministry of Finance, Report of the Task Force on Implementation of the Fiscal Responsibility and Budget Management Act, 2003. Submitted in July, 2004.

[8] Government of India, Reserve Bank of India, Handbook of Statistics, 2013-14.

[9] Gupta, S. B. (1992). Black Income in India, Sage Publications, New Delhi.

[10] Jalan, B. (1992) India’s Economic Policy- Preparing for the Twenty First Century, Penguine Books, New Delhi, 21.

[11] Kalecki, M. (1971). Selected Essays on the Dynamics of the Capitalist Economy, Cambridge University Press.

[12] Kumar, A. (1988), (August 2-9). Budget 1988-89- Diminishing Returns of Unchanged Fiscal Policy Regime, Economic and Political weekly, 719-732.

[13] Kumar, A. (1994), (April 16-23), Growth Prospects Recede as Macro-Economic Situation Slips Out of Control, Economic and Political Weekly, 953-968.

[14] Kumar, A. (1999a). The Black Economy in India, Penguin Books, New Delhi.

[15] Kumar, A. (1999b), (March 20).The Black Economy: Missing Dimensions of Micro Policy Making in India, Economic and Political Weekly,

[16] Kumar, A. (2015), (June 26). Estimating the Size of Black Economy, Paper presented at the Seminar on Black Economy in Centre for Economic Studies and Planning (CESP), JNU

[17] Kumar, A. (2017). Understanding the Black Economy and Black Money in India, Aleph Spotlight, New Delhi.

[18] Kumar, A. and Sen (1993). Proposals for National Union Budget for 1993-94: An Alternative to the Fund-Bank Dictated Union Budget, Vani Publications, New Delhi.

[19] Mansoor, A. M (1988) The Budgetary Impact of Privatization in Blejer, Mario I and Chu, Ke-young (ed.), Measurement of Fiscal Impact Methodological Issues, IMF Occasional Paper No. 59.

[20] Rakshit, M. (2005). Budget Deficit: sustainability, Solvency and Optimality, In A. Bagchi (ed.) Readings in Public Finance. New Delhi: OUP.

[21] Rangarajan, C. (2009), (12 July), Rates May Harden by Fiscal End, Business Standard, Retrieved from http://www.business-standard. com/india/news/rates-may-harden-by-fiscal-end-rangarajan/370457/. 